\section{UF 4412 and UF 4424-Red Lance-leaved Caladium Cultivars}

\author{
Zhanao Deng ${ }^{1}$ and Brent K. Harbaugh \\ Environmental Horticulture Department, University of Florida/Institute of \\ Food and Agricultural Sciences (IFAS), Gulf Coast Research and Education \\ Center, 14625 County Road 672, Wimauma, FL 33598
}

\section{Natalia A. Peres \\ Plant Pathology Department, University of Florida/IFAS, Gulf Coast Research and Education Center, 14625 County Road 672, Wimauma, FL 33598}

Additional index words. Araceae, breeding, caladium bicolor, Caladium $\times$ hortulanum, ornamental aroid

Cultivated caladiums (Caladium $\times$ hortulanum Birdsey, Araceae Juss.) are valued for their colorful and variable-shaped leaves (Harbaugh and Tjia, 1985; Wilfret, 1993). Cultivars generally are divided into three groups according to leaf shape and size: fancy-, lance-, and strap-leaved (Wilfret, 1986). Fancy-leaved caladiums produce large round-ovate to triangular leaves with three main veins, two large basal lobes partially to fully joined, and a petiole attached to the back of the leaf blade. Strap-leaved caladiums have linear leaves with one main vein and no obvious basal lobes. Lance-leaved caladiums produce leaves intermediate between fancy and strap types: leaves sagittate to cordate-lanceolate in shape, basal lobes obvious to barely obvious, and petioles attached to the base of the leaves (Deng and Harbaugh, 2006a). The majority of caladium cultivars in commercial production are fancy-leaved (Bell et al., 1998; Deng et al., 2011). However, there has been an increasing demand for lanceleaved cultivars. Florida growers, the primary supplier of caladium tubers used in the world, reported greater than $50 \%$ more acres used for producing lance-leaved caladiums in 2008 than in 1998 (Bell et al., 1998; Deng and Alleyne, 2009; Deng et al., 2011).

Plants of lance-leaved cultivars generally are more compact with smaller leaves and

Received for publication 3 Dec. 2012. Accepted for publication 27 Dec. 2012

We thank the Florida Caladium Growers Association, the Florida Foundation Seed Procedures, Inc., the USDA/TSTAR program, and the Fred C. Gloeckner Foundation, Inc. for providing part of the funding used to develop UF 4412 and UF 4424 caladiums. We thank Joyce Jones, Gail Bowman, Richard Kelly, Nancy West, and Teresa Seijo for their excellent technical support and Bates Sons \& Daughters, Classic Caladiums, and Happiness Farms for evaluating UF 4412 and/or UF 4424. The Osmocote ${ }^{\circledR}$ fertilizer used in field and greenhouse trials was donated by the Scotts Miracle-Gro Company, and the potting mix Fafard $3 \mathrm{~B}$ was donated by Fafard, Inc. (Apopka, FL).

${ }^{1}$ To whom reprint requests should be addressed; e-mail zdeng@ufl.edu. shorter petioles than fancy-leaved caladiums. Tubers produced by lance-leaved caladiums tend to be more branched (Deng and Harbaugh, 2008). Therefore, lance-leaved caladiums are adaptable to different container sizes, do not require tuber de-eyeing for pot plant production, and are less expensive and easier to ship from production sites to markets. These characteristics result in significant benefits to growers producing and marketing potted caladium plants (Deng and Harbaugh, 2008). Lance-leaved caladiums may be more resilient to wind damage, drought, sunburn, and shading than fancy-leaved caladiums and may do better than the latter in the landscape when such stresses occur (Deng and Harbaugh, 2008). However, many lance-leaved caladiums often produce small tubers (Wilfret, 1983). Tubers are both the planting stock and the crop for caladium growers. Thus, tuber yield in a $20.3-\mathrm{cm}$ container. is one of the most important factors determining a cultivar's economic value for commercial production of caladium tubers. Growers cannot produce cultivars profitably without adequate tuber yield and have to eliminate them from commercial production. Thus, developing new lance-leaved caladium cultivars with adequate tuber yield potential has been a priority breeding objective for the University of Florida (UF) caladium breeding program since its beginning in 1976.

Currently, 'Florida Sweetheart' is the most popular lance-leaved commercial cultivar of any color, and 'Florida Red Ruffles' is the most popular red lance-leaved commercial cultivar among caladium growers, greenhouse growers, and nurseries (Bell et al., 1998; Deng and Alleyne, 2009; Deng et al., 2011). Both cultivars were introduced by the UF caladium breeding program. Plants of 'Florida Sweetheart' are compact and produce wide lance leaves with a rosy color and relatively large tubers (Wilfret, 1991a). 'Florida Red Ruffles' has a compact, upright growth habit and excellent sunburn tolerance (Wilfret 1991b).

UF 4412 (Fig. 1) and UF 4424 (Fig. 2) are attractive lance-leaved cultivars with novel, distinct combinations of plant and foliar characteristics. UF 4412 leaves are heartshaped like 'Florida Sweetheart' but have a large red center and numerous netted red veins. UF 4412 plants are taller and produce longer and wider leaves than 'Florida Sweetheart' plants. UF 4424 leaves are cordatelanceolate-like 'Florida Red Ruffles' leaves but have a large, glossy, red center and numerous red, thick veins. UF 4412 and UF 4424 were comparable or superior in replicated field, greenhouse, and landscape trials

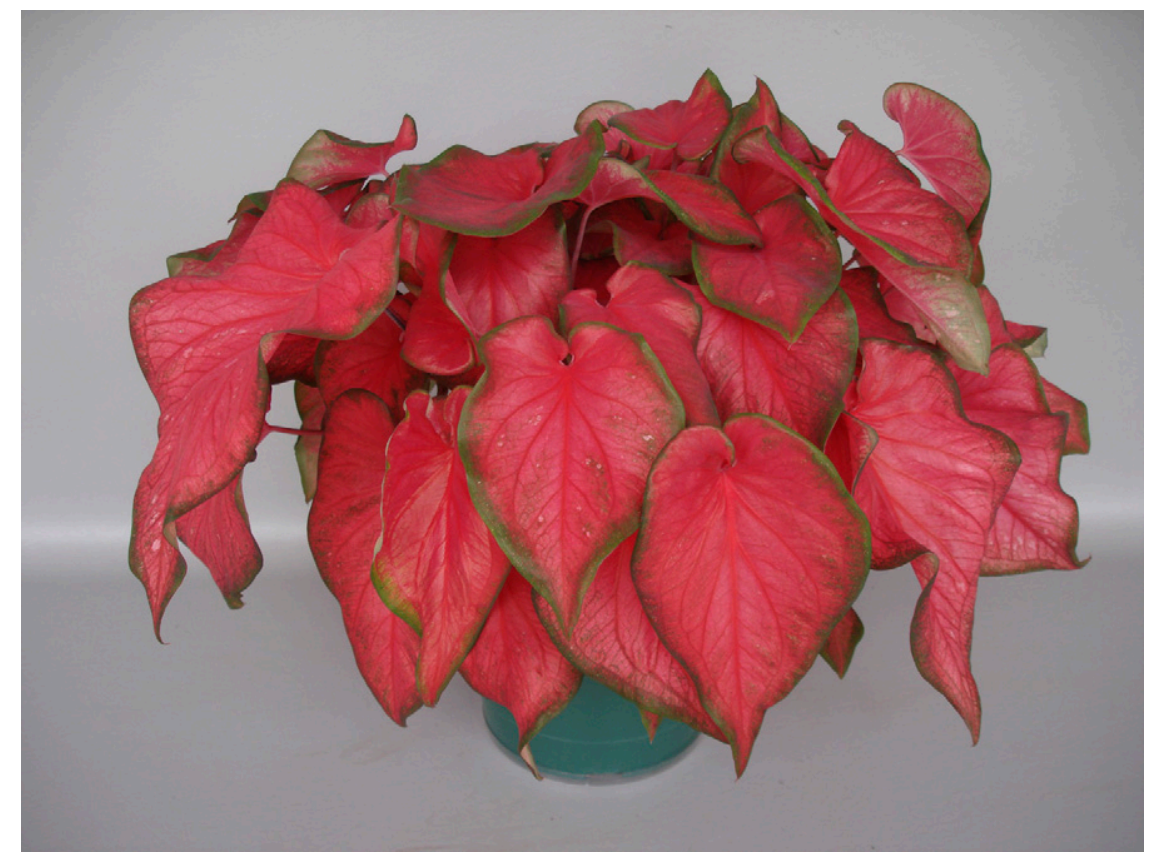

Fig. 1. A potted plant of UF 4412 ( 6 weeks old) forced from four No. 1-sized (3.8 to $6.4 \mathrm{~cm}$ diameter) tubers 
to 'Florida Red Ruffles' and 'Florida Sweetheart' in tuber yield, pot plant quality, and landscape performance. UF 4412 and UF 4424 are suitable for producing pot plants, and tuber de-eyeing was not required for forcing in small containers. These characteristics should make UF 4412 and UF 4424 economically viable and profitable cultivars for commercial production of caladium tubers. The availability of UF 4412 and UF 4424 can help expand the caladium plant palette for greenhouse growers, nurseries, and gardeners.

\section{Origin}

Both UF 4412 and UF 4424 are progeny of crosses between 'Florida Sweetheart' (Plant Patent 8,526) and 'Red Flash' (Fig. 3) that were made in Bradenton, FL, in Spring 2004. UF 4412 and UF 4424 were selected initially in Aug. 2005 and have been propagated asexually by tuber division over seven generations. Growth characteristics of these cultivars were stable and consistent. 'Florida Sweetheart' was selected as the seed parent because of its plant vigor, pot plant growth habit, bright leaf color, excellent sun tolerance,

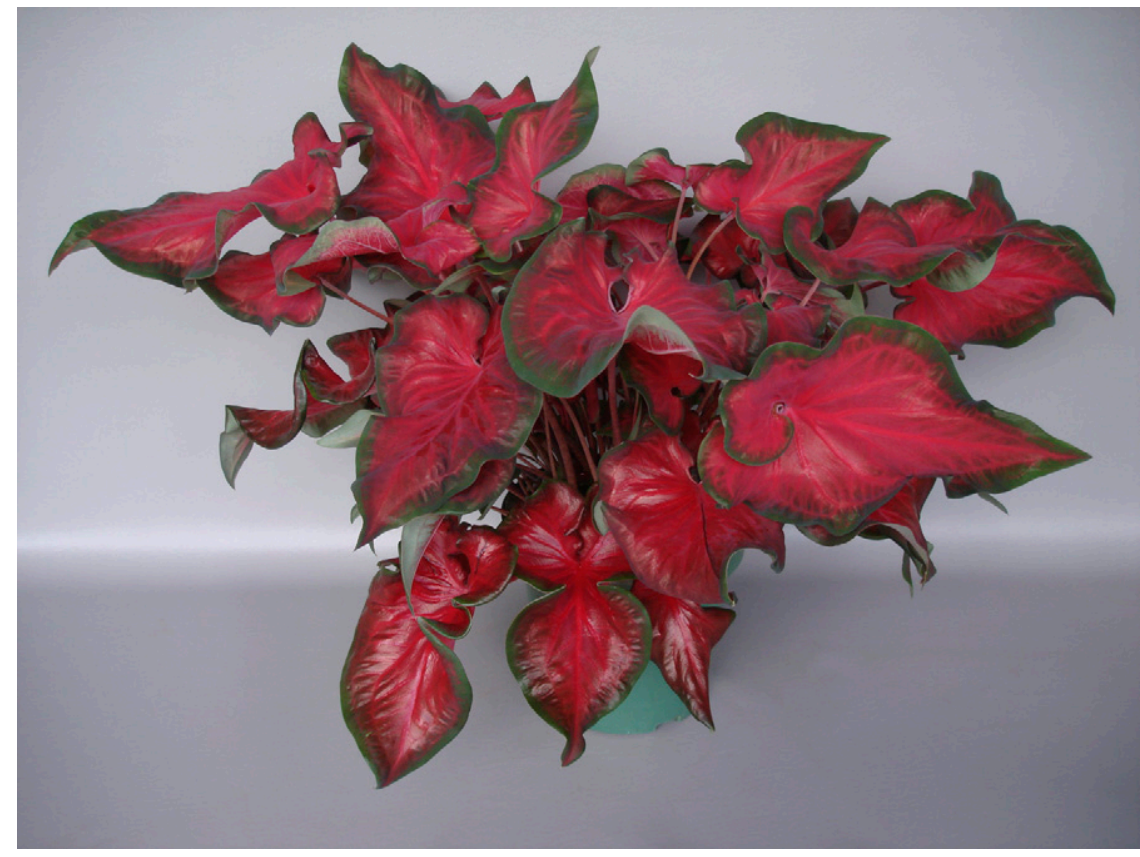

Fig. 2. A potted plant of UF 4424 ( 6 weeks old) forced from five No. 2 -sized tubers ( 2.5 to $3.8 \mathrm{~cm}$ diameter) in a $20.3-\mathrm{cm}$ container.

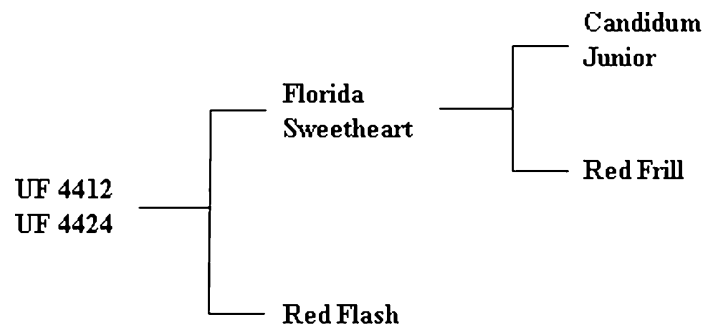

Fig. 3. Pedigree of UF 4412 and UF 4424 caladiums.

and high tuber yield potential. 'Red Flash' was used as the pollen parent because of its strong plant vigor, red leaf color, and excellent sun tolerance. 'Florida Sweetheart' was developed by Wilfret (1991a) from a 1977 cross between 'Candidum Junior' and 'Red Frill'. 'Red Flash' is an unpatented commercial cultivar reportedly selected by Frank M. Joyner in Tampa, FL, in the 1950s (Terri Cantwell-Bates, personal communication). Ancestry of 'Candidum Junior', 'Red Flash', and 'Red Frill' is unknown.

\section{Description}

Descriptions of color [e.g., Royal Horticultural Society (RHS) 200B] for plant parts are based on comparison with the Royal Horticultural Society Color Chart (Royal Horticultural Society, 1986). Three plants used for describing color were grown in $20.3-\mathrm{cm}$ containers in a $30 \%$ shaded greenhouse from No. $1(3.8$ to $6.4 \mathrm{~cm})$ de-eyed tubers.

$U F$ 4412. UF4412 plants grown in the commercial potting mix Fafard 3B (Fafard, Inc., Apopka, FL) under shade for approximately two months have an average height of $40.5 \mathrm{~cm}$ and produce 35 to 47 leaves per 
a grayed white (RHS 156C) wax. Numerous short brown speckles are present on the petioles. Jumbo tubers are multisegmented, bearing six to nine dominant buds. Tuber surfaces are brown (RHS 200D) with the cortical area yellow (RHS 12B).

\section{Tuber Yield Potential}

\section{Field experiments}

UF 4412 and UF 4424 were evaluated for tuber production at the Gulf Coast Research and Education Center in Wimauma, FL, in 2007, 2009, and 2010. The soil was EauGallie fine sand with $\approx 1 \%$ organic matter and a $\mathrm{pH}$ value between 6.2 and 7.4. Caladium plants were grown in the field using a plasticmulched raised-bed system. In 2007, ground beds ( $81 \mathrm{~cm}$ wide, $20 \mathrm{~cm}$ high) were fumigated on 3 Apr. with a mixture of $67 \%$ methyl bromide and $33 \%$ chloropicrin (by volume) at the rate of $196 \mathrm{~kg} \cdot \mathrm{ha}^{-1}$. Caladium seed pieces (tuber pieces, $\approx 2.5 \times 2.5 \times 2.5 \mathrm{~cm}$ ) were planted manually on 26 Apr. with $\approx 25.4 \mathrm{~cm}$ between-row spacing and $\approx 15.2 \mathrm{~cm}$ in-row spacing. Drip tapes were buried under the plastic mulch and delivered $\approx 6 \mathrm{~mm}$ of water to the bed per day. Fertigation (through the drip irrigation system) began when young caladium plants emerged from the soil, supplying $6 \mathrm{~N}-0.8 \mathrm{P}-3.9 \mathrm{~K}$ soluble fertilizer at the rate of $\approx 1.9 \mathrm{~kg}$ of nitrogen $/ \mathrm{ha} / \mathrm{d}$ and a total $290 \mathrm{~kg}$ of nitrogen/ha per growing season. Tubers (new crop) were dug, washed, and dried in early Jan. 2008. Dried tubers from each experimental field plot were weighed, graded, and counted in late Jan. 2008 as described by Deng and Harbaugh (2006b). Tuber grading was by the maximum diameter: Super Mammoth (greater than $11.4 \mathrm{~cm}$ ),
Mammoth (8.9 to $11.4 \mathrm{~cm}$ ), Jumbo (6.4 to $8.9 \mathrm{~cm})$, No. 1 (3.8 to $6.4 \mathrm{~cm})$, and No. $2(2.5$ to $3.8 \mathrm{~cm})$. Tuber grades and counts were converted into a Production Index (PI) to show the relative economic value of the harvested tubers per field plot: PI $=8 \mathrm{n}$ (Super Mammoth) + 6n (Mammoth) + 4n (Jumbo) + $2 \mathrm{n}$ (No. 1) $+\mathrm{n}$ (No. 2), where $\mathrm{n}=$ number of tubers in the grade.

In 2009 , field beds $(81 \mathrm{~cm}$ wide, $20 \mathrm{~cm}$ high) were fumigated on $27 \mathrm{Feb}$. with a mixture of 50\% methyl bromide and 50\% chloropicrin (by volume) at the rate of $196 \mathrm{~kg} \cdot \mathrm{ha}^{-1}$. Caladium seed pieces were planted $9 \mathrm{Apr}$. at $\approx 15$-cm spacing between rows and in rows. The irrigation and fertigation system was the same as the one used in 2007, but one teaspoon $(\approx 7 \mathrm{~g})$ of the controlled-release fertilizer Osmocote ${ }^{\circledR}(15 \mathrm{~N}-2.6 \mathrm{P}-10 \mathrm{~K}$, five to six months; Scotts Co., Marysville, $\mathrm{OH}$ ) was applied to each plant on 21 July. Tubers were dug on 30 Nov. to 2 Dec. 2009 followed by washing, drying, weighing, grading, and counting as done in 2007.

In 2010, ground beds $(91 \mathrm{~cm}$ wide, $20 \mathrm{~cm}$ high) were fumigated on 21 Mar. with PICClor $^{\circledR} 60 \quad(39 \%$ 1,3-dichloropropene and $59.6 \%$ chloropicrin; Soil Chemicals Corp., Hollister, CA) at the rate of $426 \mathrm{~kg} \cdot \mathrm{ha}^{-1}$. Caladium seed pieces were planted on $9 \mathrm{Apr}$. with $15-\mathrm{cm}$ spacing between and in rows. A seepage irrigation system, as described by Geraldson et al. (1965), was used to maintain a water table below the caladium root system. Approximately $14 \mathrm{~g}$ of Osmocote ${ }^{\circledR} 15 \mathrm{~N}-$ $2.6 \mathrm{P}-10 \mathrm{~K}$ (eight to nine months) was applied to each plant on 18 May and again on 13 Aug. Caladium tubers were dug on 3 to 6 Dec. Tuber washing, drying, weighing, and grading were conducted as described previously.
Experimental design and data analysis

Field plots were arranged each season in a randomized complete block fashion with three blocks, and each plot was $1.2 \mathrm{~m}^{2}$ and was planted with 30 caladium seed pieces. Two commercial cultivars, Florida Red Ruffles and Florida Sweetheart, were included as control cultivars or controls in each block. Analyses of variance were conducted using the PROC GLM procedure in SAS (SAS Institute, 2011) to compare the tuber yield of UF 4412 and UF 4424 to that of 'Florida Red Ruffles' and 'Florida Sweetheart'.

$U F$ 4412. This cultivar was more productive than 'Florida Sweetheart' in 2007 and was as productive as 'Florida Sweetheart' in 2009 and 2010 (Table 1). UF 4412 produced more marketable tubers (75.0 vs. 45.7) and had a greater PI (148 vs. 105) in 2007 than 'Florida Sweetheart'. UF 4412 and 'Florida Sweetheart' produced similar amounts and similar marketable numbers of tubers and generated similar PIs in 2009 and 2010. UF 4412 and 'Florida Sweetheart' shared a similar tuber-grade distribution. UF 4412 was more productive than 'Florida Red Ruffles' in two of the three growing seasons. UF 4412 produced more marketable tubers in 2007 (75.0 vs. 42.0) and 2009 (76.7 vs. 44.7) plus a higher PI in 2007 (148 vs. 85) and 2009 (146 vs. 72). However, UF 4412 and 'Florida Red Ruffles' produced similar amounts and similar numbers of tubers in 2010. The majority $(60 \%$ or more) of tubers produced by UF 4412 were in the categories of No. 1, Jumbo, or Mammoth, similar to the size distribution of 'Florida Red Ruffles' (Table 1).

UF 4424. This cultivar was as productive as 'Florida Sweetheart' in both 2009 and

Table 1. Tuber weight, production index, and grade distribution of UF 4412 and UF 4424 and two commercial cultivars grown in Wimauma, FL, in 2007, 2009 and $2010 .^{z}$

\begin{tabular}{|c|c|c|c|c|c|c|c|c|}
\hline \multirow[b]{2}{*}{ Cultivars } & \multicolumn{3}{|c|}{ Tuber } & \multicolumn{5}{|c|}{ Tuber distribution (\%) } \\
\hline & $\overline{\mathrm{Wt}(\mathrm{kg})}$ & Production index ${ }^{y}$ & Marketable (no.) & Super Mammoth & Mammoth & Jumbo & No. 1 & No. 2 \\
\hline & & & & Year 2007 & & & & \\
\hline UF 4412 & 3.5 & $148 \mathrm{a}^{\mathrm{x}}$ & $75.0 \mathrm{a}$ & & 3.3 & 13.7 & 44.4 & 38.6 \\
\hline Florida Red Ruffles & 2.7 & $85 \mathrm{~b}$ & $42.0 \mathrm{~b}$ & & 1.0 & 20.0 & 41.0 & 37.9 \\
\hline Florida Sweetheart & 3.3 & $105 \mathrm{~b}$ & $45.7 \mathrm{~b}$ & & 2.6 & 28.6 & 31.3 & 37.5 \\
\hline \multirow[t]{2}{*}{$\operatorname{LSD}(\alpha=0.05)$} & NS & 41.76 & 18.46 & & NS & NS & NS & NS \\
\hline & & & & Year 2009 & & & & \\
\hline UF 4412 & $3.6 \mathrm{a}$ & $146 \mathrm{a}$ & $76.7 \mathrm{a}$ & & 1.9 & $7.5 \mathrm{bc}$ & 65.3 & 25.4 \\
\hline UF 4424 & $3.4 \mathrm{a}$ & $135 \mathrm{a}$ & $61.0 \mathrm{~b}$ & & 4.0 & $14.8 \mathrm{ab}$ & 58.3 & 22.9 \\
\hline Florida Red Ruffles & $1.8 \mathrm{~b}$ & $72 \mathrm{~b}$ & $44.7 \mathrm{c}$ & & & $4.4 \mathrm{c}$ & 48.8 & 46.8 \\
\hline Florida Sweetheart & $3.9 \mathrm{a}$ & $136 \mathrm{a}$ & $67.3 \mathrm{ab}$ & & 1.3 & $19.5 \mathrm{a}$ & 38.9 & 40.3 \\
\hline \multirow[t]{2}{*}{$\operatorname{LSD}(\alpha=0.05)$} & 1.16 & 23.4 & 14.5 & & NS & 10.0 & NS & NS \\
\hline & & & & Year 2010 & & & & \\
\hline UF 4412 & 2.5 & 113 & 47.0 & & 4.7 & 19.2 & $56.1 \mathrm{a}$ & 20.0 \\
\hline UF 4424 & 2.4 & 108 & 44.3 & & 6.8 & 21.3 & $45.0 \mathrm{ab}$ & 26.9 \\
\hline Florida Red Ruffles & 1.9 & 109 & 40.3 & & 2.4 & 41.1 & $36.7 \mathrm{ab}$ & 19.9 \\
\hline Florida Sweetheart & 2.9 & 129 & 45.0 & & 9.2 & 42.4 & $20.8 \mathrm{~b}$ & 27.6 \\
\hline $\operatorname{LSD}(\alpha=0.05)$ & NS & NS & NS & & NS & NS & 29.1 & NS \\
\hline
\end{tabular}

${ }^{z}$ Values presented for each year are means of three plots in three randomized complete blocks; and each plot was $1.2 \mathrm{~m}^{2}$ with 30 tuber propagules planted.

${ }^{y}$ The production index is an indicator of economic value of the crop harvested and is calculated as: $\mathrm{N}(\mathrm{No} .2 \mathrm{~s})+2 \mathrm{~N}(\mathrm{No} .1 \mathrm{~s})+4 \mathrm{~N}(\mathrm{Jumbos})+6 \mathrm{~N}(\mathrm{Mammoth})+8 \mathrm{~N}$ (Super Mammoth); where $\mathrm{N}=$ number of tubers in each grade. Tubers graded by maximum diameter; No. 2 (2.5 to $3.8 \mathrm{~cm}$ ), No. 1 (3.8 to $6.4 \mathrm{~cm})$, Jumbo (6.4 to 8.9 $\mathrm{cm}$ ), Mammoth (8.9 to $11.4 \mathrm{~cm}$ ), and Super Mammoth (greater than $11.4 \mathrm{~cm}$ ).

${ }^{x}$ Mean values that share the same letters within columns are not significantly different at $P \leq 0.05$.

NS $=$ not significantly different at $P \leq 0.05$.

LSD $=$ least significant difference. 
2010 growing seasons (Table 1). The two cultivars produced similar amounts of tubers, similar numbers of marketable tubers, and similar PI in 2009 and 2010. UF 4424 was more productive than 'Florida Red Ruffles' in 2009 and as productive as 'Florida Red Ruffles' in 2010. UF 4424 produced a greater amount of tubers ( $3.4 \mathrm{~kg}$ vs. $1.8 \mathrm{~kg}$ ), a larger number of marketable tubers (61.0 vs. 44.7), and a higher PI (135 vs. 72) in 2009. UF 4424 and 'Florida Red Ruffles' produced similar amounts of tubers, similar numbers of marketable tubers, and similar PI in 2010. UF 4424 and UF 4412 produced similar tuber weights and generated similar PI in 2009 and 2010, but UF 4424 produced fewer marketable tubers than UF 4412 in 2009 . The majority $(70 \%$ or more) of tubers of UF 4424 were in the No. 1, Jumbo, and Mammoth grades (Table 1).

\section{Pot trials}

UF 4412. The suitability of UF 4412 for pot plant production was evaluated by forcing tubers in 11.4-cm containers in Spring 2008. No. 1 tubers were planted in a peat/ vermiculite mix (VerGro Container Mix A; Verlite, Tampa, FL) on 17 Apr. The study was conducted in a greenhouse with $45 \%$ light exclusion. Average daily temperatures in the greenhouse ranged from a low of $16^{\circ} \mathrm{C}$ at night to $29{ }^{\circ} \mathrm{C}$ during the day during the experiment. Potted plants were arranged on metal benches in the greenhouse in a randomized complete block fashion with eight replications. Plant height, plant width, number of leaves, and foliar characteristics were recorded on 12 June 2008,8 weeks after planting. Quality of the potted caladium plants was rated on a scale of 1 to 5 , with $1=$ very poor, few leaves, totally unacceptable as potted plants and $5=$ very attractive with many bright, colorful leaves, a full plant, a symmetrical shape, and an appropriate height.

Intact tubers of UF4412 sprouted $\approx 30 \mathrm{~d}$ after planting, $\approx 5 \mathrm{~d}$ later than 'Florida Red Ruffles' and 'Florida Sweetheart' (Table 2). UF4412 plants were 4 to $6 \mathrm{~cm}$ taller and 15 to $17 \mathrm{~cm}$ wider than 'Florida Red Ruffles' and
'Florida Sweetheart' plants. UF 4412, 'Florida Red Ruffles', and 'Florida Sweetheart' plants produced similar numbers of leaves ( $\approx 19)$, but again UF 4412 leaves were 4 to $5 \mathrm{~cm}$ longer and 1 to $3 \mathrm{~cm}$ wider. Pot-grown UF 4412 plants produced multiple bright red leaves and received significantly higher quality rating (3.8) than 'Florida Red Ruffles' and 'Florida Sweetheart' plants (2.7 to 2.9). Thus, this cultivar does not require tuber de-eyeing to produce high-quality plants, even when forced in small containers.

UF 4424. The suitability of this cultivar for pot plant production was evaluated in 11.4-cm square containers in Spring 2012. No. 1 tubers were planted either intact or deeyed in the commercial potting substrate Fafard 3B Mix (Conrad Fafard Inc., Agawam, MA) on 13 Apr. The greenhouse was covered with an aluminum shadecloth and had $\approx 35 \%$ light exclusion. Average daily temperatures ranged from a low of $17^{\circ} \mathrm{C}$ at night to $29^{\circ} \mathrm{C}$ during the day during the experiment. One teaspoon $(\approx 7 \mathrm{~g})$ of Osmocote ${ }^{\circledR}$ controlled fertilizer $(15 \mathrm{~N}-2.6 \mathrm{P}-10 \mathrm{~K}$, five to six months $)$ was applied to each pot on 13 May. Plant height, plant width, plant quality, number of leaves, and foliar characteristics were recorded on 11 June, $\approx 8$ weeks after planting.

UF 4424 produced high-quality pot plants regardless of tuber treatments (intact or deeyed) (Table 2). When tubers were planted intact, UF4424 sprouted $\approx 28 \mathrm{~d}$ after planting, $\approx 6$ to $8 \mathrm{~d}$ later than 'Florida Red Ruffles' and 'Florida Sweetheart'. Tuber de-eyeing did not cause any significant change in sprouting time in UF 4424. UF4424 plants, either intact or de-eyed, were likely to be 2 to $5 \mathrm{~cm}$ taller than 'Florida Red Ruffles' and 'Florida Sweetheart' plants but were similar in plant width. Intact or de-eyed UF 4424 plants produced similar numbers of leaves (28.8 to 36.0 per intact plant and 42.4 to 57.3 per de-eyed plant) and had similar leaf lengths (16.3 to $18.6 \mathrm{~cm}$ on intact plants and 13.0 to $14.8 \mathrm{~cm}$ on de-eyed plants) and leaf width (11.3 to $12.8 \mathrm{~cm}$ on intact plants and 8.4 to $9.8 \mathrm{~cm}$ on de-eyed plants). Pot-grown UF 4424 plants produced a superb number of bright red, glossy, wavy leaves and received highquality ratings (3.8 to 3.9 for intact plants and 4.2 to 4.8 for de-eyed plants) along with 'Florida Red Ruffles' and 'Florida Sweetheart'. These data indicate that UF 4424 tubers do not need de-eyeing to produce high-quality finished pot plants, but de-eyeing could further improve the plant quality of potted UF 4424.

\section{Landscape performance}

Landscape performance of UF 4412 and UF 4424 was evaluated on the same plots used for evaluating tuber production. A scale of 1 to 5 was used with 1 being very poor (few leaves and lack of vigor) and 5 being excellent (full plants, numerous leaves, and bright color display). Also, leaf sun tolerance was evaluated on a scale of 1 to 5 with 1 being very susceptible to sunburn (leaves having numerous sun-damaged areas or holes) and 5 being resistant to sunburn (no visible sundamaged areas). A total of eight evaluations were conducted for plant performance and sunburn tolerance over three growing seasons in July, Aug., and Sept. 2007; Aug., Sept., and Oct. 2009; and Sept. and Oct. 2010. Approximately four months after planting, plant height, number of leaves, and leaf size were measured on three plants randomly chosen from each plot.

$U F$ 4412. This cultivar exhibited excellent plant vigor and growth habit when grown in ground beds in full sun. Plants had an average height of $35.7 \mathrm{~cm}$ after growing in full sun and sandy soil for approximately four months, $\approx 13$ to $20 \mathrm{~cm}$ taller than 'Florida Red Ruffles' or 'Florida Sweetheart' plants (Table 3). Large leaves of UF 4412 had an average size of $25.1 \mathrm{~cm}$ long and $15.9 \mathrm{~cm}$ wide, $\approx 5$ to $8 \mathrm{~cm}$ longer and $\approx 2.5$ to $6 \mathrm{~cm}$ wider than 'Florida Red Ruffles' and 'Florida Sweetheart' leaves. UF 4412 plants developed a superb number of large, wide lance leaves in bright red and received very high plant performance ratings (4.2 to 4.9) in all evaluations from the three growing seasons (Table 4). UF 4412 plants' performance ratings were significantly higher than those of 'Florida Red

Table 2. Plant characteristics and performance of caladium cultivars grown from No. 1 tubers in 11.4-cm containers in a 45\% shaded glasshouse in Wimauma, FL, in 2008 or $2012 .^{2}$

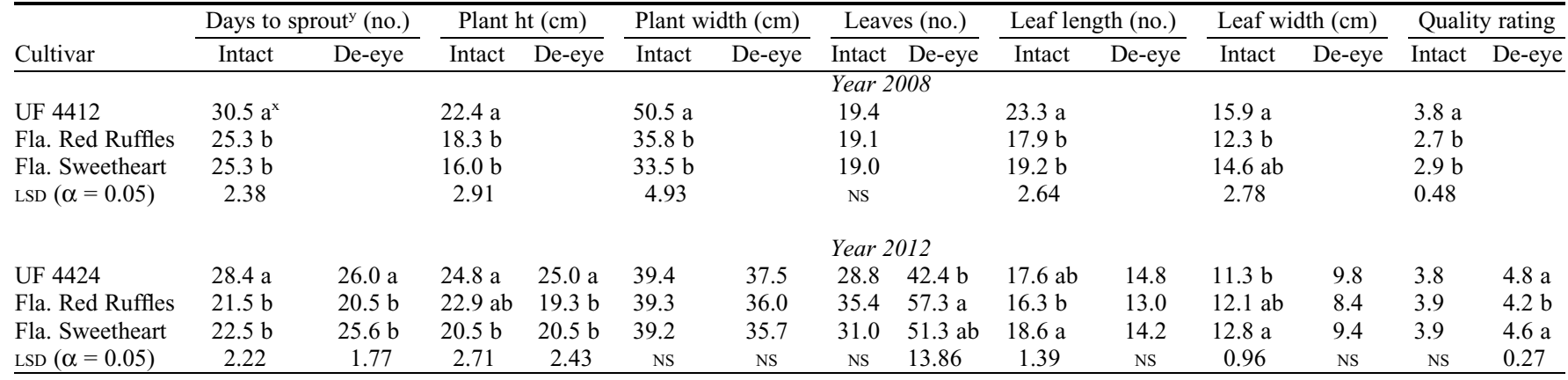

${ }^{\mathrm{z}}$ Values represent the means of eight plants produced from intact or de-eyed No. 1 (greater than 3.8 and less than $6.4 \mathrm{~cm}$ in diameter) tubers planted individually per container and data taken $\approx 8$ weeks after planting.

y Number of days from planting to the first unfurled leaf.

${ }^{\mathrm{x}}$ Mean values with columns that share the same letters are not significantly different at $P \leq 0.05$.

NS $=$ Not significantly different at $P \leq 0.05$.

LSD $=$ least significant difference. 
Ruffles' in all nine evaluations and significantly higher than those of 'Florida Sweetheart' in five of nine evaluations. UF 4412 plants maintained excellent performance throughout the growing season. Both 'Florida Red Ruffles' and 'Florida Sweetheart' are considered sunburn-tolerant cultivars. The sunburn tolerance rating of 'Florida Red Ruffles' and 'Florida Sweetheart' in 2007, 2009, and 2010 ranged from 3.5 to 5.0 and from 3.3 to 4.7 , respectively. UF 4412 plants' sunburn tolerance ratings were between 3.8 and 4.9 (Table 4), similar to 'Florida Red Ruffles' or 'Florida Sweetheart's sunburn tolerance ratings in most of the evaluations.

$U F$ 4424. This cultivar also exhibited excellent plant vigor and plant growth habit when grown in ground beds in full sun. Plants had an average height of $28.6 \mathrm{~cm}, \approx 7 \mathrm{~cm}$ shorter than UF 4412 plants, and leaves had an average of $22.9 \mathrm{~cm}$ long and $13.2 \mathrm{~cm}$ wide, $\approx 2.5 \mathrm{~cm}$ narrower than UF 4412 leaves (Table 3). UF 4424 plants were $\approx 10 \mathrm{~cm}$ taller than 'Florida Red Ruffles', leaves $\approx 6 \mathrm{~cm}$ longer and $\approx 3 \mathrm{~cm}$ wider, but produced a similar number of leaves. UF 4424 plants were also $\approx 5 \mathrm{~cm}$ taller and leaves were $\approx 3 \mathrm{~cm}$ longer than 'Florida Sweetheart'. UF 4424 between 4.2 and 5.0, similar to 'Florida Red Ruffles' (4.2 to 5.0) in four of five evaluations. UF 4424 sunburn tolerance scores were similar to 'Florida Sweetheart' (3.3 to 4.7) in plants received a sunburn tolerance score

three of five evaluations but better than 'Florida Sweetheart' in two evaluations (Table 4). These results demonstrate that UF 4424 possesses excellent sunburn tolerance for use in landscapes. UF 4412 plants grown in full sun produced a superb number of large, sunburntolerant, glossy, red leaves; they were full and very attractive and received performance ratings between 4.2 and 4.8, similar to 'Florida Sweetheart' performance ratings but significantly better than 'Florida Red Ruffles' ratings (Table 4).

\section{Recommendation}

UF4412 plants produce a superb number of brightly colored, wide lance- to heartshaped leaves like 'Florida Sweetheart', but UF 4412 leaves are novel with a bright red center and netted red secondary veins. UF 4412 is like 'Florida Sweetheart' in canopy formation, cascading from the center to the side and producing an attractive, mounding plant in the landscape. UF 4412 plants are tolerant of sunburn and can perform very well in both sunny and shady landscape locations. Similar to 'Florida Sweetheart', UF 4412 produces high-quality potted plants, even in small containers $(11.4 \mathrm{~cm}$ diameter $)$ and without de-eyeing of tubers. UF 4412 is expected to be highly suitable for producing potted plants in a wide range of container sizes or for planting in the landscape. It should be noted that UF 4412 produces larger

Table 3. Plant characteristics of UF 4412, UF 4424, and two commercial cultivars approximately four months from planting tuber propagules $(\approx 2.54 \mathrm{~cm} \times 2.54 \mathrm{~cm} \times 2.54 \mathrm{~cm})$ in full sun and ground beds (sandy soil) in Wimauma, FL, in 2007, 2009, and 2010.

\begin{tabular}{|c|c|c|c|c|}
\hline Cultivar & Plant ht $(\mathrm{cm})$ & Leaves (no.) & leaf length ${ }^{y}(\mathrm{~cm})$ & Leaf width ${ }^{\mathrm{x}}(\mathrm{cm}$ \\
\hline$\overline{\text { UF } 4412}$ & $35.7 \mathrm{a}^{\mathrm{w}}$ & 25.6 & $25.1 \mathrm{a}$ & $15.9 \mathrm{a}$ \\
\hline UF 4424 & $28.6 \mathrm{~b}$ & 23.3 & $22.9 \mathrm{a}$ & $13.2 \mathrm{~b}$ \\
\hline Florida Red Ruffles & $17.9 \mathrm{c}$ & 27.7 & $16.9 \mathrm{~b}$ & $10.0 \mathrm{c}$ \\
\hline Florida Sweetheart & $22.9 \mathrm{c}$ & 28.7 & $19.4 \mathrm{~b}$ & $13.4 \mathrm{~b}$ \\
\hline $\operatorname{LSD}(\alpha=0.05)$ & 3.14 & NS & 2.69 & 1.17 \\
\hline
\end{tabular}

zValues presented are means of three years' data from three replications and three plants measured per plot per year.

${ }^{y}$ Leaf length was measured on the largest leaves along the longest line from the leaf lobe to the leaf tip. ${ }^{x}$ Leaf width was measured on the largest leaves across the widest middle part.

${ }^{\text {w}}$ Mean values that share the same letters within columns are not significantly different at $P \leq 0.05$.

NS $=$ not significantly different at $P \leq 0.05$.

LSD $=$ least significant difference. plants and larger leaves than 'Florida Red Ruffles' and 'Florida Sweetheart'; therefore, larger spacing may be necessary for potted plant production. Also, UF 4412 tubers sprout $\approx 5 \mathrm{~d}$ later than 'Florida Sweetheart' tubers. Thus, 1 extra week may be needed to produce potted plants using UF 4412 tubers. UF 4412 is as productive as, or more productive than, 'Florida Sweetheart' in terms of tuber yield potential.

The red lance-leaf group of caladium cultivars has been dominated by 'Florida Red Ruffles' over the last 10 years. UF 4424 produces large, brightly red, glossy, widelance leaves and is distinctly different from 'Florida Red Ruffles' and UF 4412. UF 4424 tolerates sunburn very well and has demonstrated excellent performance in sunny landscapes. UF 4424 is more vigorous than 'Florida Red Ruffles' and produces taller plants with longer and wider leaves when grown in ground beds. This new cultivar can produce high-quality potted plants in small containers without tuber de-eyeing. During potted plant production, one extra week will be needed for UF 4424 because its tubers sprout 5 to $7 \mathrm{~d}$ later than tubers of 'Florida Red Ruffles'. Potted UF 4424 plants are taller (2 to $6 \mathrm{~cm}$ ) than 'Florida Red Ruffles' plants. UF 4424 is as productive as or more productive than 'Florida Red Ruffles' in tuber yield. Therefore, UF 4424 is expected to become a highly desirable new cultivar that can be of significant value to expand the market for the red lance-leaved caladium cultivars.

Although UF 4412 and UF 4424 share similarities in leaf type and color, significant differences exist in multiple aspects: 1) UF 4412 leaves are heart-shaped, whereas UF 4424 leaves are lanceolate with an elongated acute apex; 2) UF 4424 leaf margins are highly undulate, whereas UF 4412 leaf margins are only slightly undulate; 3) UF 4412 leaves have netted gray-purple secondary veins, whereas UF 4424 leaves lack noticeable netted veins; and 4) UF 4424 leaves are highly waxy, glossy, whereas UF 4412 leaves are not. UF 4412 seems to be more productive than UF 4424 in tuber yield potential, and UF 4424 seems to be more tolerant of sunburn.

Table 4. Plant performance and sunburn tolerance of UF 4412 and UF 4424 and two commercial cultivars (checks) when planted in full sun and ground beds in Wimauma, FL, in 2007, 2009 and $2010 .^{2}$

\begin{tabular}{|c|c|c|c|c|c|c|c|c|c|c|c|c|c|c|c|c|}
\hline \multirow{2}{*}{ Cultivar } & \multicolumn{8}{|c|}{ Performance rating ${ }^{y}$} & \multicolumn{8}{|c|}{ Sunburn tolerance rating ${ }^{x}$} \\
\hline & \multicolumn{3}{|c|}{2007} & \multicolumn{3}{|c|}{2009} & \multicolumn{2}{|c|}{2010} & \multicolumn{3}{|c|}{2007} & \multicolumn{3}{|c|}{2009} & \multicolumn{2}{|c|}{2010} \\
\hline UF 4412 & $4.7 \mathrm{a}^{\mathrm{w}}$ & $4.2 \mathrm{a}$ & $4.3 \mathrm{a}$ & $4.5 \mathrm{a}$ & $4.8 \mathrm{a}$ & $4.7 \mathrm{a}$ & $4.7 \mathrm{a}$ & $4.9 \mathrm{a}$ & $4.2 \mathrm{a}$ & 4.0 & 4.3 & $3.8 \mathrm{~b}$ & $4.8 \mathrm{ab}$ & $4.2 \mathrm{~b}$ & 4.9 & $4.5 \mathrm{a}$ \\
\hline Florida Red Ruffles & $3.8 \mathrm{~b}$ & $3.1 \mathrm{~b}$ & $2.9 \mathrm{~b}$ & $3.2 \mathrm{~b}$ & $3.7 \mathrm{~b}$ & $3.5 \mathrm{~b}$ & $2.9 \mathrm{c}$ & $3.3 \mathrm{c}$ & $3.5 \mathrm{~b}$ & 4.3 & 4.0 & $5.0 \mathrm{a}$ & $5.0 \mathrm{a}$ & $4.7 \mathrm{a}$ & 4.6 & $4.2 \mathrm{ab}$ \\
\hline Florida Sweetheart & $3.3 \mathrm{~b}$ & $3.1 \mathrm{~b}$ & $2.8 \mathrm{~b}$ & $4.7 \mathrm{a}$ & $4.5 \mathrm{ab}$ & $3.3 \mathrm{~b}$ & $4.7 \mathrm{a}$ & $4.3 \mathrm{~b}$ & $3.5 \mathrm{~b}$ & 4.3 & 3.8 & $4.7 \mathrm{a}$ & $4.5 \mathrm{~b}$ & $3.3 \mathrm{c}$ & 4.6 & $3.8 \mathrm{~b}$ \\
\hline $\operatorname{LSD}(\alpha=0.05)$ & 0.81 & 1.04 & 1.33 & 1.00 & 1.10 & 0.90 & 0.45 & 0.41 & 0.35 & NS & NS & 0.74 & 0.44 & 0.29 & NS & 0.58 \\
\hline
\end{tabular}

${ }^{z}$ Values presented are means of three replications in each year.

y Plants were rated on a scale of 1 to 5 with 1 being very poor, 3 fair and acceptable, and 5 being excellent in plant vigor, fullness, and color display, on 27 July, 28 Aug., and 15 Sept. 2007; 12 Aug., 15 Sept., and 8 Oct. 2009; and 14 Sept. and 12 Oct. 2010.

'Plants' sunburn tolerance was rated on a scale of 1 to 5 with 1 being very poor, 3 fair and acceptable, and 5 being excellent without showing any signs of leaf burns or holes caused by sunburn on leaf surfaces, on 27 July, 28 Aug., and 15 Sept. 2007; 12 Aug., 15 Sept., and 8 Oct. 2009 ; and 14 Sept. and 12 Oct. 2010.

${ }^{\text {w}}$ Mean values that share the same letters within columns are significantly different at $P \leq 0.05$.

${ }^{\mathrm{v}}$ This cultivar was not available for evaluation.

NS $=$ Not significantly different at $P \leq 0.05$.

$\mathrm{LSD}=$ least significant difference. 
Although extensive research and evaluations of these cultivars have been performed on small acreages, growers are encouraged to plant only limited quantities of UF 4412 and UF 4424 until they have gained experience in producing these cultivars. Standard postharvest treatment of tubers is recommended (Harbaugh and Tjia, 1985) and pre-plant hot water treatment of tubers (Rhodes, 1964) is encouraged.

\section{Availability}

The Florida Agricultural Experiment Station has applied for plant patents for UF 4412 and UF4424. Production of these cultivars is to be with a licensing agreement with the Florida Foundation Seed Producers, Inc., P.O. Box 309, Greenwood, FL 32443. Information on tuber availability and propagation agreements can be obtained from the Florida Foundation Seed Producers, Inc. (http://ffsp.net/).

\section{Literature Cited}

Bell, M.L., G.J. Wilfret, and D.A. DeVoll. 1998. Survey of caladium tuber producers for acreage of cultivars grown. Proc. Fla. State Hort. Soc. 111:32-34.

Deng, Z. and J.C. Alleyne. 2009. 2008 survey of caladium growers in Florida. 2009 FSHS (Florida State Horticultural Society) Meeting. Abstract by Section. 27 Aug. 2012. <http://www.fshs.org/ Meetings/2009/Abstracts-FSHS_2009.pdf $>$.

Deng, Z. and B.K. Harbaugh. 2006a. Independent inheritance of leaf shape and main vein color in caladium. J. Amer. Soc. Hort. Sci. 131:53-58.

Deng, Z. and B.K. Harbaugh. 2006b. 'Garden White'-A large white fancy-leaved caladium for sunny landscapes and large containers. HortScience 41:840-842.

Deng, Z. and B.K. Harbaugh. 2008. Caladium breeding: Progress in developing lance-leaved cultivars. Proc. Fla. State Hort. Soc. 121:395398.

Deng, Z., B.K. Harbaugh, R.K. Schoellhorn, and R.C. Andrew. 2011. 2003 survey of the Florida caladium tuber production industry. Univ. of Fla. /IFAS extension fact sheet, ENH 1007. 27 Aug. 2008. <http://edis.ifas.ufl.edu/EP258>.

Geraldson, C.M., A.J. Overman, and J.P. Jones. 1965. Combination of high analysis fertilizers, plastic mulch and fumigation for tomato production on old agricultural land. Proc. Soil Crop Sci. Soc. Fla. 25:18-24.
Harbaugh, B.K. and B.O. Tjia. 1985. Commercial forcing of caladiums. IFAS, Univ. of Fla. Agr. Ext. Serv. Circ. 621.

Rhodes, H.L. 1964. Effect of hot water treatment of seed tubers and soil fumigation for control of root knot on yield of caladiums. Plant Disease Reporter 8:568-571.

Royal Horticultural Society. 1986. RHS colour chart. Royal Hort. Soc., London, UK.

SAS Institute. 2011. The SAS system for Windows. Release 9.2. SAS Inst., Cary, NC.

Wilfret, G.J. 1983. Tuber production of caladium cultivars grown in a sandy soil. Proc. Fla. State Hort. Soc. 96:245-248.

Wilfret, G.J. 1986. Inheritance of leaf shape and color patterns in Caladium (Araceae). HortScience 21:750 (abstr.).

Wilfret, G.J. 1991a. Florida Sweetheart: A rose lance caladium for landscape and containers. Florida Agr. Exp. Stn., Instit. Food Agric. Sci., Univ. Fla., Gainesville, Cir. S-380.

Wilfret, G.J. 1991b. Florida Red Ruffles and Florida Irish Lace: Two new lance-leaf caladium cultivars. HortScience 31:564 (abstr.).

Wilfret, G.J. 1993. Caladium, p. 239-247. In: de Hertogh, A. and M. le Nard (eds.). The physiology of flower bulbs, Elsevier, New York, NY. 